\title{
ICT SPECIALIST SKILLS AND KNOWLEDGE - BUSINESS REQUIREMENTS AND EDUCATION
}

\begin{abstract}
This paper describes partial results of surveys realized among Czech universities and business units which aim has been to analyze current situation in demand and supply side of ICT (Information and Communication Technologies) specialists at the labor market in the Czech Republic. The demand and supply side are compared through their requirements on knowledge of ICT specialists. The results present typical "product" of Czech education system in ICT competencies. General conclusions show that majority of undergraduates do not have appropriate knowledge profile to enter ICT corporate business as qualified employees - ICT specialist without further additional training. The same fact is valid for a little less than a half of graduates at master level. During quantitative analysis, we have identified that at about 60 per cent of ICT specialists did not pass a formal ICT education. These facts show lacks in ICT oriented study programs and provoke requirement on further development of ICT oriented curricula in accordance to business requirements and needs.
\end{abstract}

\section{Key Words}

ICT specialist, education, business requirements

\section{Miloš Maryška, Petr Doucek}

University of Economics in Prague

milos.maryska@vse.cz

\section{ARTICLE INFO}

Article type

Full research paper

doi: 10.7160/eriesj.2012.050305

Article history

Received: June 24, 2012

Received in revised form: September 13, 2012

Accepted: September 14, 2012

Available on-line: September 30, 2012

Maryška, M., Doucek, P. (2012) "ICT Speicalist Skills and Knowledge - Business Requirements and Education", Journal on Efficiency and Responsibility in Education and Science, Vol. 5, No. 3, pp. 157-172, ISSN 1803-1617, [on-line] www.eriesjournal.com/_papers/article_176.pdf 


\section{Introduction}

The contemporary economic environment (Saee, 2004) places elevated emphasis on ICT skills in various fields on human activities. The same is also valid in the area of Information and Communication Technologies (ICT). For example increase of managerial abilities and skills in the area of ICT improves possibilities introduction and using of ICT in everyday economic practice and their subsequent operation. In 2010, almost $5.4 \%$ of the employed global population was working in positions of ICT professionals (OECD, 2010) in 2008, (Doucek et al, 2011). Their knowledge have to be constantly expanded and, simultaneously, the typical knowledge of ICT professionals (Frinking et al, 2005) have to be increasingly combined with other "non- ICT" knowledge, such as marketing, business, etc. (OECD, 2010), (EC, 2010). Similar conclusions were drawn by (Fernandez, 2006), who states that a combination of ICT and "non-ICT" knowledge is more important for enterprises in selecting employees than only specific ICT knowledge.

Impact of ICT on the whole economy is evaluated as positive in majority of cases. These findings were approving by numbers of studies (Brynjolfsson \& Hitt, 1996; Jorgenson \& Stiroh, 1999). The impact of ICT has been also approved by econometrics and statistical analysis for example in (Hanclova \& Doucek, 2011; Fischer \& Vltavska, 2011; Delina \& Tkac, 2010; Dorcak \& Delina, 2011). These studies prove that the economic boom at the end of nineties was subsequence of new ICT that were generally implemented and putted into use. Together, Delina (Vajda \& Delina, 2009) presents the results of ICT usage study in Slovakia based on European methodology, where weak ICT solution adoption relates to low level of e-skills and e-knowledge. In study by Delina from 2010 (Delina \& Tkac, 2010) he also revealed interesting relations between e-skills and trust into ICT. It means higher e-skills have positive impact on ICT usage through increased trust into these new technologies.

Mentioned studies lead us to reflection how is this supported by the education at the universities.

The best way how to identify the "extent of support" that universities devote to the ICT education is execution of survey among them. Really important is that we have to take into account level of studies. We have divided studies in two levels at the universities in the Czech Republic - bachelor and master study. From this paper's point of view is really important that this division is not adequately respected as by the universities so as by the enterprises.

The aim of this paper is finding and highlighting the gap between requirements of enterprises on ICT specialists' knowledge and really taught university ICT study programs. This distance is identified as the gap that should be reduced by universities based on the communication between enterprises' and universities 'representatives. Current situation at the labor market can be described as discrepancy between requirements of enterprises on ICT specialists' knowledge with knowledge that offers university ICT study programs.

This finding is confirmed by another research made by the research team at the University of Zagreb (Varga, Stiffler, Lužar-Stiffler, 2004) and by research team in Saudi Arabia (AlJabri, Fraihat, 2005). These teams in their research conclusions confirm our results that there is a big discrepancy between companies' expectations about graduates real knowledge and potential knowledge that offer the university ICT oriented study programs. From our point of view is really important that (Varga, Stiffler, Lužar-Stiffler, 2012) use in their research similar knowledge structure as has been applied in our survey (Varga, Stiffler, Lužar-Stiffler, 2012). The same approach and principles 
are applied only with little different domains in new proposal of Computing Curricula (Strawman, 2012) of the ACM.

\section{Materials and Methods}

We have defined the methodology of our survey and it was compared with methodologies other institutions or authors (CEPIS, 2012; Fernandez, 2006; Strawman, 2004; etc.).

Methodology has been divided into the following sections:

- Definition of ICT roles, particularjobs and key competencies.

- Definition of knowledge domains and knowledge profiles.

- Definition and measurements of knowledge level.

- Definition and calculation the difference between university graduates' knowledge profile and business knowledge profile.

- Methods of subject's selection (universities and economic subjects) for data collection.

- Methods used to questionnaires evaluation.

\section{ICT Roles}

We have defined six essential ICT roles (Business Analyst, Manager of ICT development, IS/ICT dealer, Developer - IS Architect, Administrator, Advanced User) in year 2005 and seven roles (Business Analyst, Manager of ICT development, IS/ICT dealer, Developer - IS Architect, Administrator, ICT Lecturer, Enterprise Architect) in year 2010. Changes were set up by changes on the labor market. All of these roles have the same definition in both surveys. New roles defined for the survey in year 2011 replaced the role Advanced user analyzed in the first survey.
There are presented only these five roles included in both surveys (Business Analyst, Manager of ICT development, IS/ ICT Dealer, Developer, Administrator) in this paper. These roles were described by key knowledge, key activities and professions usually included in the role.

The envelope of Business Analyst contents in majority of business units jobs as knowledge engineer, business consultant, standard SW implementer, information broker, competitive intelligence specialist.

Business Analyst is expected usually to dispose knowledge in:

- Modeling of enterprise processes changes, in order to make them more rapid, more effective and less costly in order to produce quality products/services.

- Optimum use of knowledge and competence of employees and business partners.

- Planning, which ICT services/applications are advantageous to use for business processes support.

Business Analyst is usually responsible in business unit for:

- Analysis, design, standardization and optimization of enterprise processes and organizational structures (financing, trade, production etc.).

- Analysis and planning of business effects resulting from IS/ ICT.

- Analysis and design of knowledge management at organization.

- IS/ICT risk analysis, business continuity.

- Proposal of ICT services supporting enterprise processes.

- Implementation and customization of standard software. 
- Proposal, design and search of information content (information services, portal, and web) needed for management support.

ICT Development and Operation Manager role contents following jobs in business: ICT Manager, Chef Information Officer, Project Manager, Operation Manager, Security Manager etc. These persons' key knowledge is mainly focused on:

- Business/ICT relations management - the role of ICT in supporting business goals.

- ICT services, processes and resources organization and management.

- Management and coordination of ICT projects.

ICT Development and Operation Managers are responsible for a lot of tasks in a unit. The most important tasks of ICT Development and Operation Manager are:

- ICT project management.

- Information strategy working-out.

- Sourcing strategy working-out.

- ICT services delivery management.

- IS/ICT enterprise operation management.

- Problem and change management.

- Risk management.

- Security management.

- IS/ICT economics management.

- Quality control and IS audit.

In time of economic crisis, every company needs the role Businessperson in ICT products and services (ICT Dealer, ICT Relationship Manager, Account Manager, Relationship Manager, etc.). This role is responsible for:
- Marketing of ICT products and services.

- ICT products and services sales.

- ICT products and services purchase.

- Preparation of agreements on supply of ICT products and services (SLA).

- Management of relationship between supplier and customer (sourcing strategy principles).

- Negotiation with partners (respecting different national and cultural environment).

To be able to work in this role employee has to know:

- Knowledge of global and local ICT markets.

- Knowledge of existing/potential partners/customers.

- Legal aspects of ICT trading.

- Negotiation strategy and tactics.

The fifth role is Developer/IS Architect which is usually working as a developer, programmer, tester, system integrator, ICT architect, systems development manager. This role has to be familiar with:

- Technologies and procedures needed for design, integration and operation of applications.

- Design and development of user-friendly applications with simplified operational requirements.

- Design of suitable technological and application architecture of IS/ICT organization.

- Management of the team of designers and developers.

Developer/IS Architect is usually responsible for:

- Analysis and design of ICT applications (on-line services, BI, effectiveness of business processes, personal/tailored application. entertainment). 
- Database design.

- Data mining.

- Programming of client, server, database and web applications.

- Grid programming.

- Application testing.

- Application documentation (design, program, operational, users).

- Maintenance and administration of application versions.

- Integration of applications.

- Design of hardware, software and data architectures.

The last role that is presented in this paper is Administrator of Applications and of ICT Infrastructure. This role is usually set up in every company which uses ICT. Administrator has to know:

- How to acquire, maintain, operate and terminate ICT infrastructure components.

- How to scale up and down the ICT infrastructure.

- How to support users of IS/ICT.

Administrator's key activities are:

- Application administration, training and support of users.

- Database administration.

- Administration of data content.

- Administration of computer network and of basic SW.

- Administration of configurations.

- Web administration.

More detail description of all identified ICT roles is presented for example in (Maryska \& Novotny, 2012).

\section{Knowledge Domain and Knowledge Level}

Main part of each survey have been aimed on detection of knowledge that enterprises requires from ICT specialists and on contrary the level of potential knowledge that universities provides students by force of their studies. This aim has been filled up through definition of 16 knowledge domains and 6 knowledge levels that are specified and described in the Table 1. We have defined 16 knowledge domains for our survey. More detail description of these domains is provided in the following Table 1.

\begin{tabular}{|c|l|}
\hline $\begin{array}{c}\text { Domain } \\
\text { ID }\end{array}$ & \multicolumn{1}{|c|}{ Name of the Knowledge Domain and Description } \\
\hline MS01 & $\begin{array}{l}\text { Process Modeling and Optimization - process } \\
\text { description, analysis and design or re-design of a } \\
\text { process, usage of selected modeling tool, and practical } \\
\text { experience in process modeling. }\end{array}$ \\
\hline MS02 & $\begin{array}{l}\text { Functionality and customization -this domain contents } \\
\text { namely deployment of software applications in order } \\
\text { to support business processes, function requirements } \\
\text { analysis, business models interpretation etc. }\end{array}$ \\
\hline MS03 & $\begin{array}{l}\text { Management ICT in organizations. The definition } \\
\text { of ICT services and decision about ICT operation and } \\
\text { operation of ICT services (internal, Business Process } \\
\text { Outsourcing (BPO), outsourcing, Software as a Service, } \\
\text { etc.), management of corporate ICT processes (COBIT, } \\
\text { ITIL, etc.), ICT services (internal, BPO, outsourcing, } \\
\text { Application Service Providing (ASP), etc.). }\end{array}$ \\
\hline MS04 & $\begin{array}{l}\text { Analysis and design of corporate ICT architecture, } \\
\text { ways and types of communications among applications } \\
\text { in enterprise information system and communications } \\
\text { with other enterprises (Electronic Data Interchange } \\
\text { (EDI), XML, etc.). }\end{array}$ \\
\hline
\end{tabular}




\begin{tabular}{|c|c|}
\hline $\begin{array}{l}\text { Domain } \\
\text { ID }\end{array}$ & Name of the Knowledge Domain and Description \\
\hline MS05 & $\begin{array}{l}\text { Software engineering - methods and tools for } \\
\text { development, testing, distribution, documentation, } \\
\text { maintenance and integration of software applications. } \\
\text { Management of small developer units. }\end{array}$ \\
\hline MS06 & $\begin{array}{l}\text { Data and information engineering - methods and } \\
\text { tools for data analysis and database design, Data } \\
\text { Warehouse and Business Intelligence applications } \\
\text { design, development and improvement. }\end{array}$ \\
\hline MS07 & $\begin{array}{l}\text { ICT knowledge - knowledge of ICT infrastructure } \\
\text { (hardware, operation systems, networks, network } \\
\text { protocols etc.). }\end{array}$ \\
\hline MS08 & $\begin{array}{l}\text { Operational excellence - management of enterprise } \\
\text { information system properties - efficiency, effectiveness, } \\
\text { reliability and security for applications and for } \\
\text { information system as well. }\end{array}$ \\
\hline MS09 & $\begin{array}{l}\text { Team leadership skills - domain is focused on } \\
\text { soft managerial skill as team management, project } \\
\text { management, techniques and tools for team } \\
\text { cooperation, risk management, management of crisis } \\
\text { situation. }\end{array}$ \\
\hline MS10 & $\begin{array}{l}\text { ICT market knowledge - structure of supply and } \\
\text { demand on ICT market, awareness of on market } \\
\text { available products and services, important suppliers, } \\
\text { software license models, pricing levels, market trends. }\end{array}$ \\
\hline MS11 & $\begin{array}{l}\text { Organizational management methods - management } \\
\text { of companies and institutions, ICT governance, } \\
\text { corporate governance }\end{array}$ \\
\hline MS12 & $\begin{array}{l}\text { Enterprise finance and economics - financing, } \\
\text { accounting, effectiveness and efficiency metrics and } \\
\text { measurement. }\end{array}$ \\
\hline MS13 & $\begin{array}{l}\text { Sales and marketing - marketing in ICT sector and } \\
\text { products, market and customer analysis. }\end{array}$ \\
\hline
\end{tabular}

\begin{tabular}{|c|l|}
\hline $\begin{array}{c}\text { Domain } \\
\text { ID }\end{array}$ & \multicolumn{1}{|c|}{ Name of the Knowledge Domain and Description } \\
\hline MS14 & $\begin{array}{l}\text { Mathematics - knowledge of mathematics and statistics } \\
\text { methods. }\end{array}$ \\
\hline MS15 & $\begin{array}{l}\text { Law - knowledge of basic act in the relation to } \\
\text { information society - digital signature act, copyright } \\
\text { act, personal data protection, the commercial code, code } \\
\text { of ethics, etc. }\end{array}$ \\
\hline MS16 & $\begin{array}{l}\text { Knowledge in business sectors - knowledge of } \\
\text { appropriate business sector - for example -civil } \\
\text { engineering, agriculture, forestry etc. }\end{array}$ \\
\hline
\end{tabular}

Table 1: Knowledge domains (Source: authors)

On the basis of a discussion with representatives of universities and enterprises in the ICT area, we have decided to apply this scale also for questioning enterprises. For enterprises, we have replaced the number of ECTS credits (European Credit Transfer System) for enterprises by the more comprehensible term "number intensive of training days". The recalculation mechanism was chosen as the ratio 1 ECTS credit $=1$ day of intensive training. There were identified following knowledge levels: Level 0 - No knowledge, Level 1 - Overview (relevant to 1-3 ECTS credits), Level 2 - Basic orientation and terminology (relevant to 4-8 ECTS credits), Level 3 - Good orientation and basic practical skills (relevant to 9-32 ECTS credits), Level 4 - Good orientation and good practical skills (relevant to 3364 ECTS credits), Level 5 - Highest knowledge quality and advanced practical skills (relevant to 65 and more ECTS credits). 


\section{Differences between Supply and Demand}

The distance between the knowledge profile of the study field and the particular professional roles' knowledge profile indicates the number of days that the enterprises have to invest into a newly employed ICT professional (graduate) from such a field of study for him (her) to attain the minimum required level of knowledge that the enterprises require for the particular professional role.

Distance between university knowledge profile UKP and business knowledge profile BKP is expressed by the number of additional intensive training days required for the graduate with knowledge profile UKP to fulfill the minimal requirements of business profile BKP. The smaller the distance is the "cheaper" the graduate of university for the relevant ICT role in business is. We have applied the modified method of distance from ideal variant for comparison between UKP and BKP profiles.

$$
D(a)=d(U K P, B K P),
$$

where

- $d$ is the function of the distance,

- vector UKP contents evaluation of each knowledge domain of UKP,

- vector $B K P$ contents evaluation of each knowledge domain of $B K P$ for each ICT business role.

Function of the distance is calculated for each knowledge domain by following metric:

$$
\begin{array}{ll}
d\left(U K P_{i^{\prime}} B K P_{i}\right)=0, & \text { for } U K P_{i}>=B K P_{i,} \\
d\left(U K P_{i^{\prime}} B K P_{i}\right)=B K P_{i}-U K P_{i} & \text { for } U K P_{i}<B K P_{i .} .
\end{array}
$$

The aggregated distance between university knowledge profile and ICT business role profile is then calculated as:
$D(a)=\sum_{i=0}^{16} \mathrm{~d}_{i}\left(U K P_{i}, B K P_{i}\right)=\sum_{j=0}^{16} \mathrm{~d}_{i}\left(U K P_{i}, B K P_{i}\right)$ and its interpretation is number of training days that have to be invested into the new enrolled ICT professional. Following discussions with representatives of enterprises and professional enterprises, we considered that 60 days of training is an acceptable limit to the number of days of extra training (acceptable distance), where the graduate is still not too expensive for the enterprises.

\section{Clustering}

Data received from universities were evaluated trough the analytical tools provided by Microsoft SQL Server platform. We have used platform MS SQL Server 2008 R/2. Analyses have been based on the data-mining (DM) principles. In the context of the principles of cluster analysts, it should be added that we used K-means algorithms (Bilmes 1998), (MacLennan et al 2009). Our analyses have been based on clustering methods in both surveys. We have analyzed data acquired from the questionnaires sent by enterprises and universities.

Cluster analysis is a set of algorithms which gather objects in defined sample of objects into groups. Groups (clusters) are based on two basic characteristics:

- objects are the most similar in the cluster,

- clusters are the most different. 

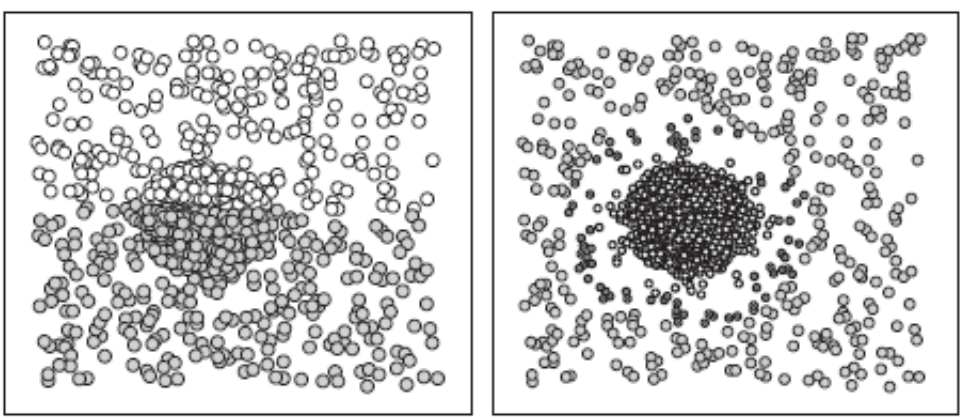

Fig. 1: Clustering based on K-means (left) and EM algorithm (right) source: (MacLennan, Tang \& Crivat, 2009)

University study fields were segmented in four clusters at bachelor level and in four clusters at master level through above mentioned analytical tools. Each cluster contains ICT study fields with rather similar characteristics. Detailed information about cluster is described in (Doucek et al, 2007).

\section{Survey Among Business Units}

The survey among business units have been realized through professional agency that used the CAWI (Computer Aided Web Interviewing) and CATI (Computer-Assisted Personal Interviewing) methods. The survey has respected structure of enterprises in the Czech economy and it also took into account facts like dependence on ICT (three categories) and number of employees (six categories). Based on these criterions, we have defined sample of business units.

The basic set of economic entities was thus divided into 18 strata on the basis of six size categories and three categories based on the dependency of the sector on information technologies. Probability sampling without replacement was performed for the individual strata. There is no unambiguously identifiable subgroup of economic entities in the sample of examined economic entities. This fact is a result especially of the sizes of the economic entities, which cover a wide range of values. This is then related to the fact that the number of ICT professionals in the examined economic entities is similarly variable. We took into account all these facts in preparation of the survey in that we required a greater fraction of examined economic entities in all the entities in the given subgroup for subgroups where a smaller number of entities could be anticipated (e.g. large entities with high dependence on ICT).

In the survey in 2006, the surveyed sample was set at 1002 entities (see Table 2).

\begin{tabular}{|l|c|c|c|c|c|c|c|}
\hline & $\mathbf{0}$ & $\mathbf{1 - 9}$ & $\mathbf{1 0 - 4 9}$ & $\mathbf{5 0 - 2 4 9}$ & $\mathbf{2 5 0 - 9 9 9}$ & $\mathbf{1 , 0 0 0 +}$ & Total \\
\hline MIT & 56 & 28 & 28 & 28 & 37 & 16 & $\mathbf{1 9 3}$ \\
\hline SIT & 56 & 56 & 56 & 56 & 71 & 36 & $\mathbf{3 3 1}$ \\
\hline VIT & 56 & 110 & 160 & 122 & 26 & 4 & $\mathbf{4 7 8}$ \\
\hline Total & 168 & 194 & 244 & 206 & 134 & 56 & $\mathbf{1 , 0 0 2}$ \\
\hline
\end{tabular}

Table 2: Structure of the Observed Sample 2006 (Source: authors)

We performed the second survey at the end of 2010 and it was also carried out utilizing the experience and base of a private company that performs surveys as its sphere of business. The structure of the sample of economic entities differed slightly from the first survey in the survey performed in 2010. There was a fundamental change in the classification of the economic entities on the basis of the size. In the second survey, we distinguished only three groups of employees. We excluded the groups with 0 and 1-9 employees from the survey on the basis of experience from the first survey in 2006 and on the basis of recommendations of experts from the Czech Statistical Office. The groups with 250-999 and 1000+ employees were combined 
in group 250+. The final sample of economic entities contained 1011 economic entities in the division according to Table 3.

The factor of dependence of the entities on ICT remained with the same conditions as was established in the survey in 2006.

\begin{tabular}{|c|c|c|c|c|}
\hline & $\mathbf{1 0 - 4 9}$ & $\mathbf{5 0 - 2 4 9}$ & $\mathbf{2 5 0 +}$ & Total \\
\hline MIT & 45 & 46 & 44 & $\mathbf{1 3 5}$ \\
\hline SIT & 57 & 474 & 98 & $\mathbf{6 2 9}$ \\
\hline VIT & 66 & 142 & 39 & $\mathbf{2 4 7}$ \\
\hline Total & 168 & 662 & 181 & 1,011 \\
\hline
\end{tabular}

Table 3: Structure of the Observed Sample 2010 (Source: authors)

\section{Survey Among Universities}

We have selected all universities in the Czech Republic that provided study fields in the area of ICT. This condition was met in case the study field's name containing some of following words: "information, technology, software, web, data mining" etc. Selection has been carried out at the data of the Institute for Information on Education that provides data from the Register of Students in the Czech Republic.

Each of the surveys was based on "exhaustive survey" among universities effective in the ICT education area and their study programs. There was sent standardized questionnaire to each of selected university. Universities were asked for filling in the questionnaire for each ICT related study programs they provide. After defined time the questionnaires that have been sent by universities back to researchers, were processed by tools for data processing and data analysis (ETL - Extract-TransformLoad and data-mining). (Maryska, 2009)
We monitored several variables in the survey:

- the total number of students newly registered for study in ICT fields of study, the numbers studying in ICT fields of study, the number of graduates and the number of unsuccessful students in ICT fields of study. We determined these characteristics for the $2001-2009$ period, for which data are available in the official statistics of the Institute for Information in Education and the Ministry of Education, Youth and Sports;

- the number of credits that students can obtain in their study for each of the 16 analyzed knowledge domains;

- key identification data for the fields of study - whether this is a classical bachelor's, subsequent master's (connected two-year study after completion of bachelor's study) or five-year master's study program (five-year master's study programs are the "pre-Bologna" fields of study, whose recertification was completed in the 2006/2007 school year and which are now gradually being terminated).

Methods of school selections and methods used to questioning schools and enterprises are entailed described for example in (Doucek, Maryska \& Novotny, 2012).

\section{Results and Discussion}

We performed the survey among universities repeatedly in 2006, 2009 and 2011. This article will consider only the results of the research performed in 2006 and 2011. The detail information about response rate is presented in Table 4 . 


\begin{tabular}{|c|c|c|c|c|c|c|}
\hline & \multicolumn{3}{|c|}{2006} & \multicolumn{3}{|c|}{2011} \\
\hline & 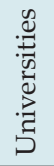 & 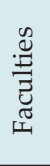 & $\frac{\infty}{0}$ & 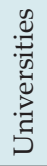 & 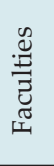 & $\frac{n}{0}$ \\
\hline Identified & 34 & 65 & 249 & 31 & 71 & 376 \\
\hline Answers & 24 & 53 & 203 & 21 & 29 & 196 \\
\hline $\begin{array}{l}\text { Response } \\
\text { rate in \% }\end{array}$ & 71 & 82 & 82 & 68 & 41 & 52 \\
\hline
\end{tabular}

Table 4: Response For Survey (Source: authors)

Differences among requirements of enterprises and supply of universities (through knowledge of their graduates) are presented in following parts of our article.

Other view on the data base of responses is the share of the study programs according to the types of faculties in our statistical sample.

\begin{tabular}{|l|c|c|c|}
\hline Type of Faculty/Type of Study & Bachelor & $\begin{array}{c}\text { Master 2 } \\
\text { years }\end{array}$ & $\begin{array}{c}\text { Master } \\
5 \text { years }\end{array}$ \\
\hline Economic & 15 & 6 & 4 \\
\hline Electro technical & 5 & 8 & 8 \\
\hline Information technologies & 15 & 40 & 39 \\
\hline Pedagogical & 12 & 7 & 12 \\
\hline $\begin{array}{l}\text { Other Technical (civil engineering, } \\
\text { machinery, transport) }\end{array}$ & 6 & 7 & 2 \\
\hline Medicine & & 1 & \\
\hline Total & 53 & 69 & 65 \\
\hline
\end{tabular}

Table 5: Number of Study Programs According to the Types of Faculties 2011 (Source: authors)
Other detail analysis according to study level is presented in following chapters.

\section{Bachelor Study Programs}

We have evaluated questionnaires from 23 faculties which provide 53 study programs on the bachelor level of study. Table 6 presents share of faculties in each cluster of the survey.

\begin{tabular}{|l|c|c|c|c|c|}
\hline Type of Faculty/ Cluster & $\begin{array}{c}\text { Bc-A } \\
2011\end{array}$ & $\begin{array}{c}\text { Bc-B } \\
2011\end{array}$ & $\begin{array}{c}\text { Bc-C } \\
2011\end{array}$ & $\begin{array}{c}\text { Bc-D } \\
2011\end{array}$ & Total \\
\hline Economic & 8 & 2 & 5 & 0 & 15 \\
\hline Electro Technical & 3 & 2 & & 0 & 5 \\
\hline Information Technologies & 7 & 0 & 2 & 6 & 15 \\
\hline Pedagogical & 4 & 7 & 1 & 0 & 12 \\
\hline $\begin{array}{l}\text { Other Technical (civil } \\
\text { engineering, machinery, } \\
\text { transport) }\end{array}$ & 4 & 1 & 0 & 1 & 6 \\
\hline Total - Bachelor level & 26 & 12 & 8 & 7 & 53 \\
\hline
\end{tabular}

Table 6: Number of Study Programs According to the Type of Faculty 2011 - In Clusters (Source: authors)

Fig. 2 takes in it the information about the potential knowledge and skills offered by respondent faculties in bachelor level of study. 


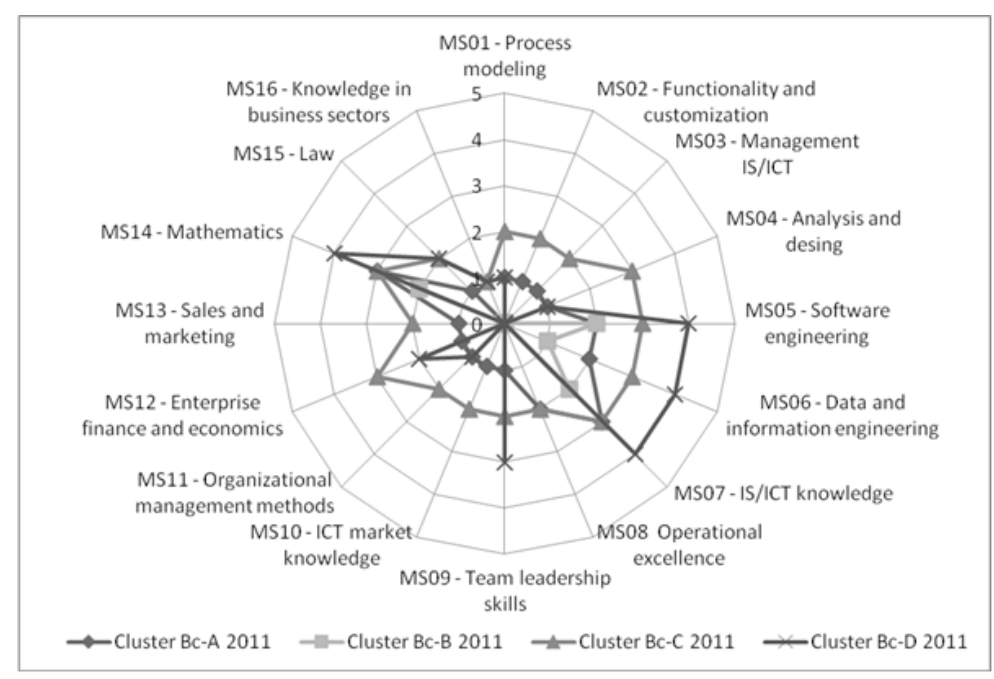

Fig. 2: Bachelors` Potential Knowledge Profile (Source: authors)

Identified clusters at bachelor level in year 2011:

- Bc-A 2011 - consists of study programs having low level of specific ICT business education. Our work hypothesis is that ICT education is "additional" to specific knowledge from other non ICT domains (e.g. transportation or chemistry). Study programs in this segment are focused mainly on software engineering, data engineering and ICT infrastructure without any other knowledge. Such selected parts of ICT give to graduate students only briefly overview of the whole problematic and general information. The skill level three is quite low for teaching these types of skills. All the skill levels are also under the median calculated through all investigated segments. This cluster contains mainly economic faculties and information technologies faculties.

- Bc-B 2011 - This segment offers harmonic education in "exact sciences". Education is focused on ICT area with added value in the statistics, marketing and enterprise finance and economics. This specialization gives perspective to a graduate either to be a lower level ICT manager, junior business analyst with farther master study level. This cluster contains namely pedagogical faculties.

- Bc-C 2011 - offers common education in "classic" ICT. This kind of education represents knowledge in areas of ICT services, software engineering, data engineering and ICT infrastructure, operational excellence, communications and team leadership. Additional is provided statistics - part of "exact science". These graduates have potential for lower junior computer specialist positions. This cluster contains the rest of economic faculties.

- Bc-D 2011 - the most complex knowledge with accent not only to ICT education, but also to general education in economics, organization and enterprise knowledge (see Fig. 2). The D segment with whole scope of taught knowledge offers potential for future graduates to enter into the level of upper management either in ICT or in other areas of business or as a business consultants or analysts (after finishing relevant master studies). This cluster is represented by information technologies faculties.

The Fig. 3 presents gaps at bachelor level in the years 2006 and 2011. The gaps are presented for each of above mentioned roles and clusters.

There is visible the small gap for the roles Administrator in Fig. 2 in year 2006, but there is only one Administrator role 
(Bc-B 2006) in this Fig. 2 that meet the lowest defined level of knowledge that are acceptable by business. All other roles exceed defined limit 60 additional days and graduates in these clusters are too expensive for enterprises.

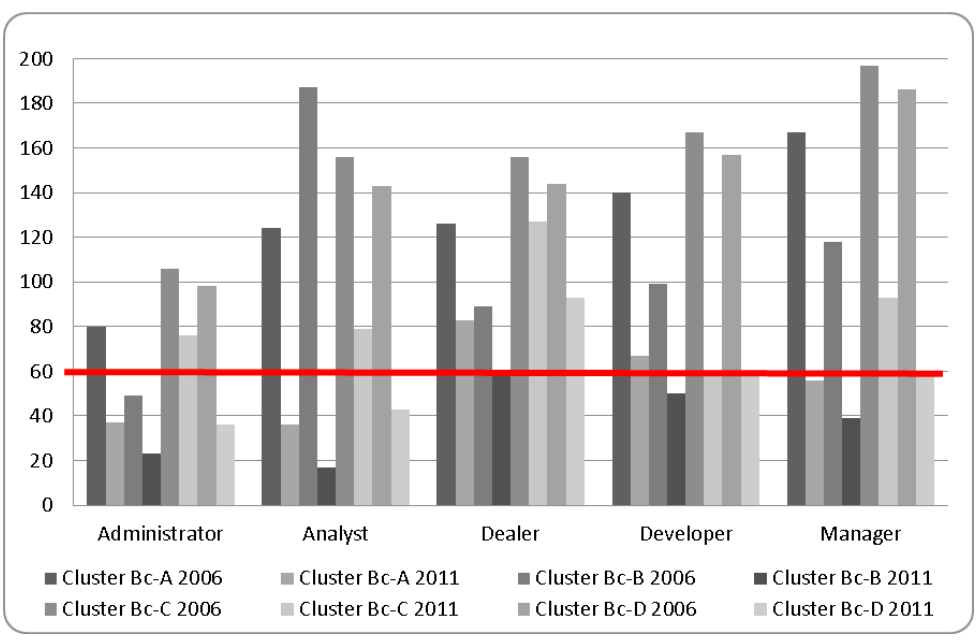

Fig. 3: The Gap 2006 and 2011 - Bachelor Studies (Source: authors)

Much better situation was detected at bachelor level in year 2011. It is clear visible, that the requirements are fulfilled at least once in all analyzed roles at bachelor level. The best situations have been detected in roles Administrator and Analyst. Graduates, entering the role Administrator and Analyst, have the structure of knowledge profile that almost corresponds to enterprises' requirements.

\section{Master Study Programs}

It was more difficult to build up a consistent picture about the master study potential knowledge and skills in ICT oriented studies. The main problem represent still running two types of master studies in our country. The ordinary two years master study according to Bologna declaration and heritage of the past education system - the five years master study. Number of study programs according to the type of faculties included into master level study survey and its shares on clusters are presented in Table 7.65 study programs included in the survey is provided by 16 faculties.

\begin{tabular}{|l|c|c|c|c|c|}
\hline $\begin{array}{l}\text { Type of Faculty/ } \\
\text { Cluster }\end{array}$ & $\begin{array}{c}\text { Mgr5-A } \\
2011\end{array}$ & $\begin{array}{c}\text { Mgr5-B } \\
2011\end{array}$ & $\begin{array}{c}\text { Mgr5-C } \\
2011\end{array}$ & $\begin{array}{c}\text { Mgr5-D } \\
2011\end{array}$ & Total \\
\hline Economic & 1 & 1 & 2 & 0 & 4 \\
\hline Electro Technical & 1 & 2 & 5 & 0 & $\mathbf{8}$ \\
\hline $\begin{array}{l}\text { Information } \\
\text { Technologies }\end{array}$ & 7 & 1 & 21 & 10 & 39 \\
\hline Pedagogical & 5 & 5 & 2 & 0 & $\mathbf{1 2}$ \\
\hline $\begin{array}{l}\text { Other Technical } \\
\text { (civil engineering, } \\
\text { machinery, transport) }\end{array}$ & 0 & 1 & 0 & 1 & $\mathbf{2}$ \\
\hline Total - Master Level & 14 & 10 & 30 & 11 & 65 \\
\hline
\end{tabular}

Table 7: Number of Study Programs According to the Types of Faculties 2011 - In Clusters (Source: authors)

Reamark: The medicne faculty (Table 5) is not included into this presentation, because there was no bachelor study programm identified for this master study programm for aggregation.

Fig 4 presents aggregated (knowledge from bachelor level of study and on master level are aggregated into one summary in each domain) potential knowledge of graduates after five years 
of study on appropriate faculty for Bologna stody programmes. For study programmes that do not belong to Bologna declaration are aggregated information about potential knowledge withhin the whole study programm - obviously for five years.

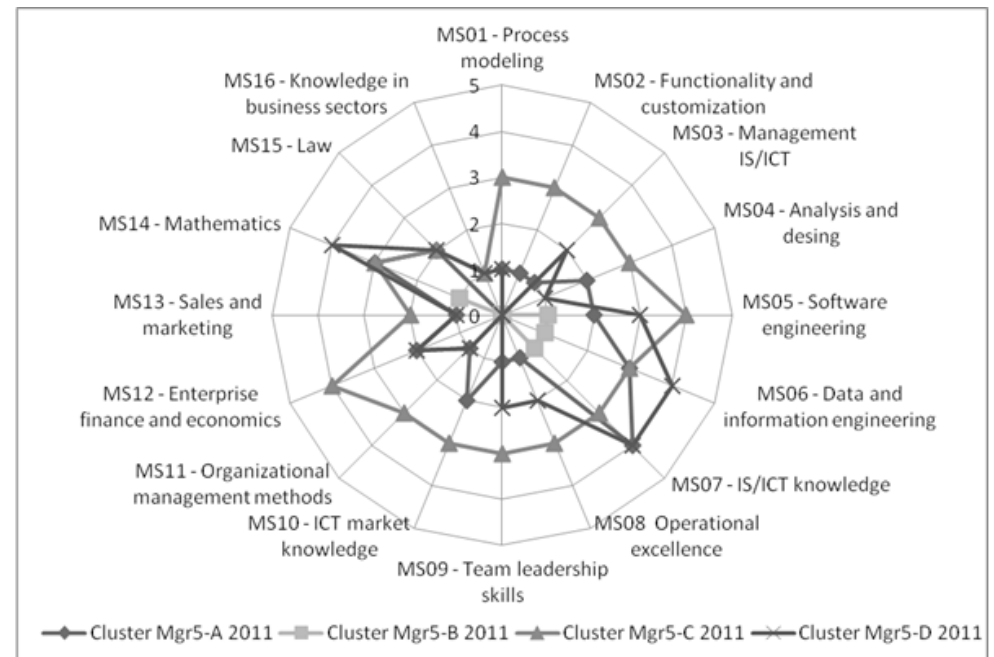

Fig. 4: Masters` Potential Knowledge Profile (Source: authors)

Identified clusters at master level in year 2011:

- Mgr5-A 2011 - consist higher level of ICT knowledge in selected ICT knowledge domains (MS06, MS07) which are supplement to other non-ICT knowledge domain. This structure can be explained by study programs included in this cluster. This cluster contains 14 faculties. From these 14 faculties is $50 \%$ of Information technologies faculties and $35 \%$ of pedagogical faculties.

- Mgr5-B 2011 - Study programs included in this cluster do not provide almost any ICT knowledge. The highest level of
ICT knowledge is on level 1. Knowledge of ICT is probably only supplements to other primary knowledge. This cluster contains namely pedagogical faculties.

- Mgr5-C2011-cluster provides themostcomplexknowledge. Accent is not devoted only to ICT education, but also to general education in other non-ICT knowledge domains (economics, organization and enterprise knowledge). Study programs included in this cluster offers potential for future graduates to enter into the level of upper management either in ICT or in other areas of business or as a business consultants or analysts. Information technologies faculties represent $70 \%$ of all faculties included in this cluster.

- Mgr5-D 2011 - offers higher education in selected ICT knowledge domains. The knowledge structure is similar to cluster Mgr5-A 2011. This kind of education represents knowledge especially in areas of Software engineering, Data and information engineering and IS/ICT knowledge. Additional is provided mathematics - part of "exact science". These graduates have potential for lower junior computer specialist positions. This cluster contains the rest of Information technologies faculties.

Similar results were detected at the master level, too. The difference is in the size of gap. The master level shows lower gaps than bachelor level - this was the expected result. It is worth mentioning clusters that have at master level bigger gap than at bachelor level. This is caused by fully five years studies that are not under Bologna declaration schema yet or by study fields that are in their name words like information technology, software etc. but the content of them does not contain majority of ICT business oriented courses. This fact is especially valid for cluster Mgr5-C 2011. We have identified increased gap in this cluster in comparison to year 2006. 
Requirements on roles Administrator and Analyst are met in clusters Mgr-A, Mgr-B and Mgr-C in both analyzed years. On contrary role Dealer and Manager is not met in clusters Mgr-A and Mgr-C in both analyzed years. Other results are presented in Fig. 5.

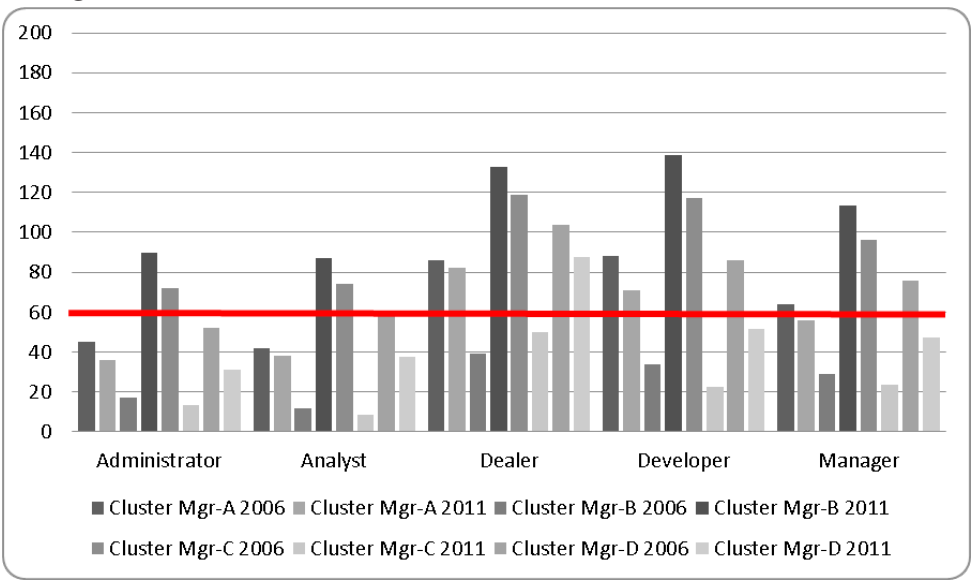

Fig. 5: The Gap 2006 and 2011 - Master Studies (Source: authors)

\section{Conclusions}

Immediate results of data evaluation of the ICT education supply side in the Czech Republic study programs are:

- ICT oriented study programs significantly differ in the level of knowledge provided to the student.

- Bachelor study programs do not provide sufficient knowledge spectrum for their graduates to enter the ICT business on leading positions without additional training in the Czech Republic. They are too "expensive" for further education in enterprises. It also depicts the situation in the Czech Republic, where only about one third of ICT graduates do not continue with the master studies (Doucek \& Maryska, 2012). Bachelor study programs are then designed as not standalone, but rather as prerequisites for the master studies.

- There are not enough relevant students and graduates with required ICT knowledge profiles in the Czech Republic. Especially roles Business Analysts and IS/ICT Dealer are not covered by the actual ICT education system in Czech Republic at all. But the same situation is valid for the role Enterprise Architect as it was also presented in (Gala \& Jandos, 2010).

- Although we have seen, that the gaps were changed among both surveys - the gaps are smaller in the second survey, we have to highlight, that the enterprises requirements were smaller in survey in year 2010 than in year 2006 (Doucek et al, 2012) and on the other university knowledge profiles haven't been essentially changed in time. (Maryska \& Novotny, 2012)

These findings should result into bettering up university graduates profiles. This can be achieved for example by:

- Building up the network between businesses oriented experts, universities and middle schools in order to coordinate the education of ICT in the whole country.

- Setting up of the methodology for evaluation of competitiveness of ICT related study programs across the country and possibility their evaluation to business requirements.

- Identification of gaps in ICT education system - missing courses and study programs for education for some specific business roles (for example IS Architect). 
- All ICT oriented study curricula must be regularly maintained and evaluated by practice. To the same conclusion came also for example Varga, Stiffler, LužarStiffler (2004).

\section{Acknowledgements}

Paper was elaborated with support of Grant Agency of the Czech Republic - projects P403/10/0092 „Advanced Principles and Models of Managing Business Informatics", "P403/11/1899 Sustainability Support of SME Based on ICT Innovation" and the IGA 409061 project of University of Economics Prague.

\section{References}

Al-Jabri, I., Fraihat, M., H. (2005). Professionals in Saudi Arabia. URL: http://faculty.kfupm.edu.sa/MISAC/imjabri/pub/IIMA1. pdf. citation: 14.7. 2012.

Bilmes, J.A. A Gentle Tutorial of the EM Algorithm and its application to Parameter Estimation for Gaussian Mixture and Hidden Markov Models (On-line 1998), citied 20.7. 2012, http:// crow.ee.washington.edu/people/bulyko/ papers/em.pdf

Brynjolfsson, E., Hitt, L. M. 1996. Paradox lost? Firm-level evidence on the returns to information systems spending. Management Science. 1996, vol. 42, issue 4,ISSN 0025-1909. http://dx.doi.org/10.1287/mnsc.42.4.541

CEPIS. 2012. EUCIP e-Competence Brochure Interior. http://www. cepis.org/media/CEPIS_ECOMPETENCE_BROCHURE_ INTERIOR_10OCT_LR1.pdf. Accessed 10 March 2012

Delina, R., Tkac, M. 2010. The Impacts of Specific ICT Solutions on Productivity. In: IDIMT-2010 Information Technology - Human Values, Innovation and Economy. Linz : Trauner, 2010, ISBN 978-385499-760-3. WOS:000288345500002
Dorcak,P.,Delina, R.2011.Vplyvelektronickýchmarketingových podnikových riešení na ekonomickú výkonnost'. In: Ekonomický časopis. Roč. 59, č. 1 (2011). ISSN 0013-3035.

Doucek, P., Novotny, O., Pecakova, I. Vorisek, J. 2007. Lidské zdroje v ICT - Analýza nabídky a poptávky po IT odbornicích v ČR. Professional Publish. ISBN 978-80-86946-51-1

Doucek, P.; Kunstova, R.; Maryska, M. 2011. Do We Have Enough ICT Specialists in the Period of eDependency? Bled 12.06.2011 - 15.06.2011. In: Creating Solutions for the Individual, Organisations and Society [CD-ROM]. Maribor : University of Maribor, 2011, ISBN 978-961-232-247-2.

Doucek, P., Maryska, M., Novotny, O. 2012. Requirements on the competence of ICT managers and their coverage by the educational system - experience in the Czech Republic. Journal of Business Economics and Management. ISSN: 1611-1699. DOI: 10.3846/16111699.2012.658436,

Doucek, P., Maryska, M. a kol. 2012. Konkurenceschopnost ICT sektoru 1. vyd. Praha. Professional Publishing., 253 pp., ISBN97880-7431-077-5.

EC. 2010. European Commision. Europe's Digital Competitiveness Report. ISBN 978-92-79-15829-2

Fernandez, J. 2006. Evaluating, computing, education programs against real world needs. JCSC 21. č. 4/2006

Fischer, J., Vltavska, K. 2011. National accounts: useful data source for analysis of Competitiveness in ICT industries. Radenci 07.11.2011 - 09.11.2011. In: Statistical Days - Statistični dnevi. Ljubljana : Narodna in univerzitetna knjižnica. ISBN 978961-239-236-9. 
Frinking, E.; Ligtvoet, A.; Lundin, P.; Oortwijn, W. 2005. The Supply And Demand of E- Skills in Europe, September 2005, Prepared for the European Commission and the European e-Skills Forum, http://www.eskills.cedefop.europa.eu. Accessed 20 June 2011EC. 2010. European Commission. "Europe's digital competitiveness report". ISBN 978-92-79-15829-2

Gala, L., Jandos, J. 2010. Enterprise Architecture Based Innovations: Competencies Perspective. Jindřichův Hradec 08.09.2010 - 10.09.2010. In: IDIMT-2010 Information Technology - Human Values, Innovation and Economy. Linz : Trauner, 2010, s. 33-40. ISBN 978-3-85499-760-3. WOS:000288345500003

Hanclova, J., Doucek, P. 2011. Education and ICT Sector in the EU (Panel-National Application). Praha 09.06.2011 - 10.06.2011. In: Efficiency and Responsibility in Education. Praha : Czech University of Life Sciences in Prague. ISBN 978-80-213-2183-0.

Jorgenson, D. W.; Stiroh, K. J. 1999. Information technology and growth. The American Economic Review. May 1999, vol. 89, issue 2, s. 109.115. ISSN 0002-8282. http://dx.doi.org/10.1257/ aer.89.2.109

Maryska, M., Novotny, O. et al. 2012. Lidské zdroje v ICT nabídka a poptávka v České republice. 1. vyd. Praha. Professional Publishing. ISBN 978-80-7431-082-9.

Maryska, M., Novotny, O., Doucek, P. 2010. ICT Knowledge Analysis of University Graduates. In: IDIMT-2010 Information Technology - Human Values, Innovation and Economy. Linz : Trauner. ISBN 978-3-85499-760-3. WOS:000288345500013

MacLennan, J., Tang, Z., Crivat, B.; Data Mining with SQL Server ${ }^{\circledR}$ 2008. Wiley Publishing, Inc., Indianapolis, Indiana, 2009. ISBN: 978-0-470-27774-4.

OECD. (2010). Information Technology Outlook 2010. Paris: OECD Publishing. 299 p. ISBN 978-92-64-08873-3.
Saee, J. 2004. Internationalisation strategy for education in the 21ST century. Journal of Business Economics and Management 2004 (on-line), 2005, vol. 5, no. 2. ISSN: 1611-1699. URL: http://www. tandfonline.com/doi/pdf/10.1080/ 16111699.2004.9636071.

Strawman, J. (2004). Computing curricula 2004 overview report including a guide to undergraduate degree programmes, In: computing, Strawman Draft, ACM/AIS/IEEE, 1, http://www.acm. org/education/curricula.html, 2004, citied 20.7. 2012.

Strawman, J.( 2012). Computer Science Curricula 2013. Strawman Draft. February 2012. http://ai.stanford.edu/users/ sahami/CS2013//strawman-draft/cs2013-strawman.pdf. Citied 14.7. 2012.

Vajda, V., Delina, R. 2009. Výskum stavu elektronického obchodu v slovenskom priemysle. In: Ekonomie a management. Vol. 12, no. 3. ISSN 1212-3609.

Varga, M., Stiffler, Ch., Lužar-Stiffler, V. (2004). Evaluating IT Knowledge Requirements for Business Professionals. URL: http://bib.irb.hr/datoteka/149808. Evaluating_IT_Knowledge_ Requirements_for_Business_Professionals_ITI2004.pdf. Citied 14.7. 2012 